\title{
Recognising Unpaid Care in Private Pension Schemes
}

\author{
Myra Hamilton* and Cathy Thomson** \\ * Social Policy Research Centre, UNSW Australia \\ E-mail:m.hamilton@unsw.edu.au \\ ** Social Policy Research Centre, UNSW Australia \\ E-mail: CM.Thomson@unsw.edu.au
}

Parents and carers often have interrupted workforce histories, causing gaps in their pension contributions and hence significantly lower retirement incomes. In some countries, to ameliorate these inequalities, carer credits have been introduced to maintain public pension contributions during periods of workforce absence. But improvements to credits in public schemes have taken place alongside a shift to private pensions that widens inequalities for carers. Introducing carer credits to private pensions is one method of addressing these inequalities. A search for examples of credits to private schemes in OECD countries revealed that, at present, they are rare and limited. This article sets out the design features and principles that should underpin carer credits to private pensions.

Key words: Pensions, privatisation, credits, care, gender.

\section{Introduction}

Providing unpaid care to a child or to a family member with disability, a long-term illness or frailty due to old age carries a retirement income penalty. A person's pension entitlement, in most countries, is linked to workforce participation and lifetime earnings. People who provide care often have interrupted workforce histories, significantly lower retirement incomes and are at greater risk of poverty in old age. As women take on a greater proportion of caring responsibilities than men, they are more likely to have low incomes in old age (Vlachantoni, 2012; ACEOWM, 2013). In almost all EU member states, women over sixty-five are on average poorer than men (Foster, 2014).

Periods of absence from the workforce or reduced workforce participation due to caring responsibilities will have a direct impact on a carer's lifetime earnings and retirement incomes, but also creates opportunity costs for future labour market participation and career progression that further affect income in old age (AHRC, 2013b; OECD, 2015). Women's lower retirement income is also due to gender inequalities in pay (Vlachantoni, 2012). Research suggests that people with caring responsibilities may be less well remunerated when they undertake paid work, with evidence of both motherhood and carer 'pay penalties' (Thomson et al., 2008; AHRC, 2013b). Women's interrupted workforce participation and the gender pay gap affect their capacity to accumulate an adequate level of retirement savings. In some EU countries, more than a third of women have no pension entitlement at all, and among those who do, the value is on average 40 per cent lower than men's (ACEOWM, 2013; Bettio et al., 2013).

In coming years, inequalities in old age created by care provision will become a more pressing issue (Vlachantoni, 2012) as population ageing creates greater demand for unpaid 
care of ageing relatives (Pickard et al., 2000; Geerts et al., 2012; Pickard, 2015) and global economic conditions place greater pressure on pension systems (Foster, 2014). Over the last few decades, various policies and services to support carers have been developed and implemented across countries, in recognition of their contribution and of the longterm health, social and financial impacts of caring. These include national carers policy frameworks and strategies; processes to identify and assess carers' needs; specific services designed to support carers, such as respite services; legislative mechanisms to reconcile caring and employment; and financial support (Colombo et al., 2011; Courtin et al., 2014).

In recognition of the retirement income penalty faced by people providing care, governments in many countries have introduced 'carer credits' into their public old age pension schemes. Carer credits are usually state-funded contributions that are made to a person's public pension while they are out of the workforce providing care. Over the last few decades, many governments have improved the value and coverage of their carer credits (Price, 2007; Fultz, 2011) (though the climate of fiscal austerity over the last few years has seen proposals to reduce their generosity (OECD, 2015)). While there is a long way to go in reducing the gender inequalities in public pension schemes around the world, and these measures will do little to improve the pensions of women already living on low pensions, these measures do go some way to ameliorating the disadvantage experienced by people providing care.

This progress in public schemes has taken place alongside a broader shift towards private provision in old age and, in particular, towards mandatory (or quasi-mandatory ${ }^{1}$ ) private pensions (Holzmann, 2012; Ebbinghaus, 2015). Private pensions are contributory savings mechanisms that are (generally) fully funded, that is, individuals contribute throughout their working lives to their own savings account from which their pension is paid in later life. In 2013, contributions to private pensions were mandatory or quasi-mandatory in eighteen of thirty-four OECD countries (OECD, 2013), and in others contributions were voluntary but heavily encouraged through taxation concessions.

While carer credits in public schemes have loosened the link between lifetime contributions and income in old age, the shift towards private pensions has tightened this link. This undermines progress made in public schemes in compensating for time spent caring and widens inequalities in pension outcomes, particularly for carers with interrupted work histories (Behrendt, 2000; Ginn, 2001; Ginn and Maclntyre, 2013). If this shift continues, growing numbers of carers will reach old age with little to support themselves. Despite this, little policy attention has focused on measures within mandatory private pension schemes that may address some of the inequalities that they create. We urgently need to consider how to address the retirement income penalty that increasingly prominent mandatory private pension schemes place on carers.

One valuable suggestion here is to change the taxation treatment of private pensions so that it is more progressive, as the concessional taxation treatment of private pensions benefits high income earners and does little to augment the retirement savings of those with interrupted lifetime earnings (Hughes and Sinfield, 2004; Davidson, 2012). This would be an important move in closing the gap in retirement savings. But this method alone only has the potential to close the gap so far, and would do more to reduce the benefits enjoyed by higher income earners than to improve the retirement incomes of those providing care. As a result, some scholars, policymakers and advocacy organisations around the world have called for carer credits in mandatory private pension schemes (i.e. Olsberg, 2004; AHRC, 2013a). 
Drawing on a review of international scholarly literature and publicly available grey literature, this article provides the first policy review and conceptual analysis of the policy of carer credits in private pension schemes. The research sets out to identify existing models of carer credits in private pension schemes, focusing on mandatory or quasi-mandatory schemes, and to assess their design features, their advantages and their disadvantages. The authors found that examples of carer credits in private schemes are rare, and those that do exist are in their early stages, vary considerably in their principles and design features and are limited in the extent to which they are capable of addressing the inequalities experienced by people who provide care. Further, these examples have been introduced in the absence of comprehensive policy or scholarly debate about how we might understand, design and evaluate carer credits in private pension schemes.

In the first review of what governments around the world are doing in this policy space, this article presents examples of carer credits in private pension schemes that emerged from the review, before analysing their design features and areas of divergence and similarity, in search of an 'exemplar' model of carer credits in private pension schemes. Then drawing on lessons learned from credits in public pension schemes, a set of ideal design principles is presented. Finally, the article provides the first conceptual analysis of this policy approach, examining where it fits into the principles that underpin public and private retirement incomes systems around the world.

\section{Background: pension architectures and closing the gender gap}

This section sets out the basics of pension system design to provide a picture of where pension credits in private pension schemes, the key focus of the paper, fit into overall pension architectures. Most countries have a multi-tier pension system made up of a combination of public and private pension schemes. The OECD (2013) offers a taxonomy with three tier-types, or levels: ${ }^{2}$

- First tier pensions: basic public social assistance-style pensions underpinned by the principles of poverty alleviation and redistribution, which are flat rate and often means tested.

- Second tier pensions: mandatory, contributory public or private savings mechanisms designed to produce some form of income replacement in older age. This tier is the most complex and includes both public social insurance schemes and mandatory (or quasi-mandatory) private savings schemes. Individuals accumulate savings based on their workforce participation, earnings or contributions throughout their life-course.

- Third tier: voluntary savings, often encouraged by government through incentives or concessions.

Most countries have some form of first and second tier public pension and voluntary private savings (third tier). A growing number also have second tier mandatory (or quasi-mandatory) contributions to private pensions. First tier schemes are not based on workforce participation or earnings and have flat-rate benefits that produce equitable outcomes for carers and non-carers. However, public and private second tier schemes, because of their link to workforce participation and earnings throughout the life course, produce a significant retirement income penalty for carers (Mohring, 2014).

In many countries, second tier contributory public pension schemes developed as the main component of their pension systems in the twentieth century (OECD, 2013). In 
response to the significant inequalities these schemes create for those with interrupted workforce histories, most governments in countries with second tier public schemes have introduced 'carer credits', which recognise time spent bearing and rearing children or caring for a family member with a disability or illness by crediting their public pension while they are out of the workforce providing care. Over the last twenty years, credits in public pensions have improved in both value and coverage.

The strengthening of carer credits in second tier public pension schemes has been accompanied by a shift towards private pension provision, and second tier private pension schemes are an increasingly important part of many countries' retirement incomes arrangements. The shift towards second tier private pension schemes is part of a broader shift in international retirement incomes policy over the last few decades that has seen governments encourage individuals to provide for their own old age from private means. This trend has seen a greater emphasis on private pensions, often supported by generous taxation concessions, and a shift from defined benefit to defined contribution pension schemes, which moves the risk associated with retirement pension accumulation from employers to individuals (Foster, 2014). Though second tier public pensions still form the main pillar of most countries' pension schemes, private pensions are becoming an increasingly dominant part and this has prompted many scholars and policymakers to describe the international trend as the 'privatisation' of pensions (i.e. Orenstein, 2008; Ebbinghaus, 2015).

Increasingly dominant private pension schemes, which are closely linked to income throughout the life-course, widen inequalities in pension outcomes, particularly for those outside of the workforce or in part-time work due to caring responsibilities (Samek Lodovici et al., 2011; ACEOWM, 2013). The shift towards private pensions, therefore, is 'sharpen[ing] the pension penalties women incur when they restrict their earning capacity in order to care for others' (Ginn and Arber, 2000: 149). The shift has also limited the redistributive potential of the state, by reducing the levers it has access to in ameliorating some of the disadvantage experienced by women and carers.

In recognition of the extent to which private pension schemes widen gender inequalities and fail to recognise periods spent caring, governments in several countries are developing mechanisms for crediting a person's private pension while they are out of the workforce providing care. While there is a considerable body of work examining credits in public pensions, little is known about what credits in private pensions might look like, and the principles and design features that might guide their development.

\section{Method}

In search of an 'exemplar' model of carer credits in private pension schemes, the authors conducted a review of international scholarly literature and international publicly available grey literature such as political and policy documents (published in English). The review emerged from of a large study conducted in 2012 and funded by the Australian Human Rights Commission that set out to explore better methods of recognising care in Australia's retirement incomes system. The review, which was updated in 2015, consisted of a search of academic literature through Proquest social sciences databases using keywords concerning credits (such as 'carer credits', 'care credits' and 'pension credits'), broader terms concerning pension system design (such as 'private pension $/ \mathrm{s}$ ', 'privatisation' and 'age pension/s') and combining these in various ways with terms such 
as 'gender', 'women', 'inequality/ies', 'care' and 'carer'. The review also included grey literature from the OECD, the European Union, various non-government organisations and single country governments where it was publicly available and in English. The papers included in the review (approximately forty in total) were therefore a mix of journal articles published in academic journals and discussion papers produced by government and non-government bodies. The discussion papers in most cases provided considerably more detail about the policy arrangements. We reviewed a substantial number of papers on public carer credits in search of discussion or analysis of private carer credits. Most, but not all, papers were focused on the gendered dynamics of contemporary pension arrangements/reform. Of the papers that specifically focused on carer credits, many were comparative in nature.

By carer credits in private pension schemes, we refer to allowances, subsidies or contributions made to private pensions to compensate for losses during periods spent caring. The review found no explicit discussion or analysis of this type of credit. Instead, details of credits in private pensions were often embedded in complex accounts of a country's pension system, and, once identified, the authors were required to delve deeper to ascertain the exact details of the measure. The authors excluded examples of private pension credits that were proposed by governments but not legislated, such as a measure currently being proposed by the Australian Liberal/National Coalition Government.

The review revealed very few examples of carer credits in private pension schemes. Before presenting a discussion of these examples, the next section will provide a detailed overview of existing pension credits in public pension schemes to reveal the design features of public pension credits and trends in the recognition of care provision in pension systems internationally. It presents this overview in some detail because, later in the article, lessons are drawn out for mandatory private pension credits based on what has been learnt from public pension credits.

\section{Carer credits in second tier public pension schemes}

Second tier, contributory public pension schemes can be flat rate or earnings-related. In flat-rate second tier public pension schemes, carer credits are usually in the form of years towards a contributions history. In earnings-related second tier public pension schemes, credits usually take the form of financial credits towards a pension account. In flat-rate schemes, a person's pension entitlement is based on the number of years that they have contributed to the social insurance scheme. To receive the full pension, they must have contributed to social insurance (and therefore participated in paid work) for a minimum number of years (AHRC, 2013b). In Britain's flat-rate pension, for example, this is called having a full contributions record. Individuals who have contributed for thirty (rising to thirty-five) or more years receive a full pension (OECD, 2015). Those with fewer years of contributions receive a lower rate of pension. People who take time out of paid work to provide unpaid care and therefore have fewer than thirty years of contributions receive a lower rate of pension in their old age. To reduce some of this disadvantage, for each year spent providing care, the government provides a one year 'credit' to their contribution record, or reduces by one year the required balance for a full contribution record, which increases their pension entitlement (AHRC, 2013b). ${ }^{3}$

Carer credits can also be in the form of a financial credit to the person's pension account while they are providing care. In earnings-related second tier public pension 
Table 1 Characteristics of carer credits in public pension schemes

\begin{tabular}{llll}
\hline \hline Type of care & $\begin{array}{c}\text { Dependent children } \\
\text { (up to age 18 years) }\end{array}$ & $\begin{array}{c}\text { People with disability, } \\
\text { chronic illness, frail } \\
\text { older people } \\
\text { Point credits (in } \\
\text { points-based pension } \\
\text { systems) }\end{array}$ & $\begin{array}{c}\text { Financial credits } \\
\text { (imputed earnings) }\end{array}$ \\
Time credits (years) & $\begin{array}{c}\text { Linked to receipt of } \\
\text { family payment or } \\
\text { tax credit }\end{array}$ & $\begin{array}{l}\text { Linked to } \\
\text { characteristics of the } \\
\text { person receiving } \\
\text { care }\end{array}$ \\
\hline \hline
\end{tabular}

schemes, the value of the financial credit is generally based on one of three methods: a proportion of earnings prior to leaving the workforce; a percentage of national average earnings; or a proportion of the national minimum wage (AHRC, 2013b). ${ }^{4}$ In Luxembourg, for example, credits are calculated based on the person's earnings prior to leaving the workforce, whereas in France credits are flat-rate, provided to all parents at a proportion of the minimum wage (OECD, 2015). Other schemes, such as Britain's, combine a financial credit with a time-based one (AHRC, 2013b), although this has recently been replaced by a new public pension and accompanying system of carer credits. While there are a few exceptions, such as Denmark and Sweden (OECD, 2015), in most carer credit schemes, where a credit of financial value (rather than time) is made to an individual's pension balance, credits are made to notional accounts; that is, the credit is not a real contribution made to an individual pension account but rather a credit towards an individual's notional pension balance in an unfunded pay-as-you-go scheme (AHRC, 2013b).

In the case of carer credits for parents, the duration of the credit is based on the age of the child, providing credits to the pension account of the parent from the birth (or adoption) of the child until the child reaches a certain age (AHRC, 2013b). In some countries, such as Sweden, an individual is entitled to credits for the time that they are on paid parental leave and in countries such as Canada, Finland and Britain, entitlement to carer credits is 'piggybacked' onto receipt of a family payment or tax credit (Fultz, 2011). In most countries with credits for carers of people with disability or illness, credits are provided for as long as the carer is in receipt of a carer-based income support payment (e.g., Britain) or the care recipient is in receipt of a disability-based income support payment (e.g., Germany). Carer credits are often paid for through general taxation revenue (Jankowski, 2011), but are occasionally shared with the individual and/or the employer (AHRC, 2013b). In sum, the structural features of carer credits in public pension schemes are set out in Table 1.

\section{Improving carer credits in public pension schemes}

In recognition that carer credits were not adequately compensating parents for periods spent caring for a young child and were not compensating informal carers for periods spent caring for someone with disability, a long term illness, or frailty due to old age, many governments have now improved the value and coverage of the carer credits in 
their second tier public pension schemes. The improvements include making credits more generous in value or duration and extending the credits to include more parents and carers. For example, countries with credits for 'informal care' now include Austria, Czech Republic, Denmark, Finland, Germany, Ireland, Italy, Lithuania, Luxembourg, Poland, Slovakia, Norway and Britain (Vlachantoni, 2008; Jankowski, 2011; AHRC, 2013b; Courtin et al., 2014). In some countries, such as Finland, France and Britain, the credits have become easier to access (AHRC, 2013b). In Britain's flat-rate public pension, for example, the number of years required for a full contributions record was reduced (DWP, 2006). ${ }^{5}$ In several countries, credits were increased in value. In Germany, the value was increased to 100 per cent of the average wage (Fultz, 2011). In some countries, the eligibility criteria governing access to the credits were altered to broaden the population eligible. For example, in France credits were expanded to include fathers (in 2010), and in Britain credits were extended in 2011 to grandparents who provide regular childcare for their grandchildren (Fultz, 2011). In other countries, credits have been made more flexible. In Germany, in 2001 credits were made available to parents who continued to provide care but returned to work part-time, and in Japan, since 2005 the one-year period during which time the parent can receive the credits changed from the child's first year of life to any time in the first three years (Fultz, 2011; AHRC, 2013b).

These changes have been introduced with the goals of improving the extent to which periods spent caring are compensated in second tier public pension schemes and of improving the adequacy of the retirement incomes of parents and carers (Samek Lodovici et al., 2011). Few evaluations of the effectiveness of carer credits have been conducted and the results are inconclusive. Overall, the evaluative literature suggests that carer credits in public pensions have had the effect of modestly improving women's retirement incomes (Evandrou and Glaser, 2003; Jankowski, 2011; AHRC, 2013b). Financial credits are more effective than time credits at improving women's pensions, particularly earningsrelated (rather than flat-rate) financial credits (Jankowski, 2011). All types of credits are more likely to benefit higher income women, and the effectiveness of carer credits could therefore be improved by targeting credits to low income women (Steinhilber, 2003; Jankowski, 2011). One method of doing this is to ensure that carer credits are accessible to parents and carers who are outside of the paid workforce when they commence care. Linking eligibility for carer credits to periods of parental leave excludes this important group of parents and carers. In some countries, this issue is addressed by linking carer credit eligibility to receipt of an income support payment (AHRC, 2013b). As women's retirement incomes are not only affected by periods outside of work but also by periods of part-time work while caring, the evaluative literature suggests that continuing to provide credits when an individual returns to work part-time potentially mitigates the effects of periods of low income while combining part-time work and care (Fultz, 2011).

Hence, changes to the value and coverage of carer credits in public pension schemes have improved credits for parents, and, importantly, have made credits available to informal carers of people with disability or illness. Research suggests that these changes have been positive, though small, steps in ameliorating the retirement income penalty associated with care provision. Continuing to improve the extent to which public schemes produce adequate and equitable pension outcomes is vital to the standards of living experienced by carers in their old age (Evandrou and Glaser, 2003; Price, 2007; Renga et al., 2010). There are lessons to be learnt from developments of carer credits in public schemes for the emergence of credits in private schemes. 


\section{Carer credits in private pension schemes}

The review revealed that the carer credits emerging in private pension schemes are in their infancy and vary across countries. All of the examples of carer credits to private pensions identified in this review are set out in Table 2. Some examples in Table 2, such as those in Sweden and Germany, are currently in place. Others, such as those in Hungary and Poland, have been affected by austerity measures in the last few years that dismantled large parts of their private pension systems (OECD, 2015). These examples have still been included in Table 2 as the objective was to shed light on possible models of private pension credits, regardless of whether or not they remain in place.

In Table 2, the first four rows include models of credits to second tier mandatory private pensions. In one instance (Poland), the state provides the credit or subsidy directly to the individual's savings, and in another instance (Hungary), the state provides a family/parental allowance from which the individual must pay a proportion into their retirement savings. Sweden and Chile do both. In Sweden, while caring for a young child, individuals are required to pay the compulsory 7 per cent employee private pension contribution from their benefit income, and the state pays the employer contribution directly into the individual's account. In Chile, individuals are required to pay 10 per cent of their parental leave payment into their private savings account, and the state provides women with one voucher for each child to compensate their savings when they retire. Denmark offers a different but interesting model in which the state credits the individual's public pension doubly to compensate for the losses in both the public and private systems. Britain provides the only example of state-mandated employerfunded contributions to private pensions during periods of care. Employers must make contributions to their employees' occupational pensions during periods of statutory maternity leave. In Germany's voluntary private pension scheme, individuals with children receive higher tax subsidies. While the German system is voluntary and only accessible to higher income earners, it nonetheless provides a different model worth considering. All existing schemes are complex, restricted in coverage, low in value and therefore limited in the extent to which they can compensate for loss in savings during periods spent caring.

\section{Trends and lessons learned}

The review revealed that, to date, no country has a comprehensive state-mandated system for recognising care in their private pension system. All existing carer credits in private pension schemes are confined to childcare and are not available to carers of a person with disability, a long-term illness or frailty due to old age (AHRC, 2013b). In different countries, credits to private pension schemes are made by the state, by individuals or, in one case, by employers. In several countries, the state takes over the employer component of the contribution while the individual is outside of the workforce providing care (AHRC, 2013b). In Sweden and Denmark, for example, the state takes over the earnings-related employer contribution during periods of care (OECD, 2015).

In other cases, individuals are required to contribute a proportion of their income support or parental leave payment into their pension account. Credits made by individuals from their income support payments are often very low, and unlikely to compensate for the loss in retirement income associated with time spent caring. The adequacy of credits made by individuals from their parental leave payments will depend on the nature of a 
Table 2 Examples of carer credits in private pension schemes*

\begin{tabular}{|c|c|c|}
\hline & Private pension scheme & Credits awarded in private scheme \\
\hline Hungary** & $\begin{array}{l}\text { Employers and employees } \\
\text { shared the mandatory } \\
\text { contribution to the public } \\
\text { PAYG earnings-related } \\
\text { scheme. Of this, } 9.5 \text { per cent } \\
\text { of their earnings was } \\
\text { redirected into a } \\
\text { fully-funded private savings } \\
\text { account. }\end{array}$ & $\begin{array}{l}\text { Parents outside of the workforce caring for } \\
\text { children could receive an } \\
\text { earnings-related parental leave benefit for } \\
\text { the first twenty-four months, or a child } \\
\text { care allowance (at the value of an income } \\
\text { support payment) until the child's third } \\
\text { birthday. During this time, parents were } \\
\text { required to pay } 9.5 \text { per cent of their } \\
\text { parental leave or child care allowance } \\
\text { into their individual savings account } \\
\text { (Fultz and Steinhilber, 2004; OECD, } \\
\text { 2011; OECD, 2015). }\end{array}$ \\
\hline Poland** & $\begin{array}{l}\text { Individuals contributed } 12.22 \\
\text { per cent of their earnings to } \\
\text { the public earnings-related } \\
\text { scheme and } 7.3 \text { per cent to a } \\
\text { fully-funded individual } \\
\text { account. }\end{array}$ & $\begin{array}{l}\text { The state credited the notional unfunded } \\
\text { public account and the funded individual } \\
\text { private account for people on maternity } \\
\text { leave, based on a fictional salary of the } \\
\text { minimum wage. The state therefore } \\
\text { provided a credit to the individual's } \\
\text { private savings account at } 7.3 \text { per cent of } \\
\text { minimum wage (Fultz and Steinhilber, } \\
\text { 2004; OECD, 2011). }\end{array}$ \\
\hline Chile & $\begin{array}{l}\text { Individuals are required to } \\
\text { contribute } 10 \text { per cent of } \\
\text { their earnings into a private, } \\
\text { fully-funded individual } \\
\text { savings account. }\end{array}$ & $\begin{array}{l}\text { In Chile, there are two forms of } \\
\text { compensation for periods outside of work } \\
\text { due to child rearing. First, the government } \\
\text { pays an earnings-related parental leave } \\
\text { benefit to parents for up to twenty-four } \\
\text { weeks. During this time, the parents must } \\
\text { contribute } 10 \text { per cent of their benefit } \\
\text { income to the mandatory private savings } \\
\text { account. A second form of compensation } \\
\text { is paid to women at the time they retire. } \\
\text { The individual receives one voucher from } \\
\text { government to the value of } 10 \text { per cent of } \\
\text { the minimum wage over an eighteen } \\
\text { month period, plus interest, for each child } \\
\text { (Arza, 2012; OECD, 2015). }\end{array}$ \\
\hline Sweden & $\begin{array}{l}\text { Individuals make compulsory } \\
\text { contributions of } 18.5 \text { per } \\
\text { cent of earnings (employees } \\
\text { pay } 7 \text { per cent and } \\
\text { employers pay the } \\
\text { remainder) of which } 16 \text { per } \\
\text { cent goes into a notional } \\
\text { public pension account and } \\
2.5 \text { per cent goes into a } \\
\text { fully-funded, (private) } \\
\text { individual account. }\end{array}$ & $\begin{array}{l}\text { When out of work caring for a young child } \\
\text { under four, individuals are required to } \\
\text { pay the employee pension contribution of } \\
7 \text { per cent from their benefit income and } \\
\text { the state pays the employer contribution. } \\
\text { If the individual was not in work before } \\
\text { assuming childcare responsibilities, the } \\
\text { credit is calculated as a proportion of } \\
\text { average earnings. Hence, the state pays a } \\
\text { credit that contributes to both the } \\
\text { notional public pension account and the } \\
\text { fully-funded private pension account } \\
\text { (OECD, 2015). }\end{array}$ \\
\hline
\end{tabular}


Table 2 Continued

\begin{tabular}{|c|c|c|}
\hline & Private pension scheme & Credits awarded in private scheme \\
\hline Denmark & $\begin{array}{l}\text { Mandatory contributions to } \\
\text { privately-administered } \\
\text { occupational pension funds. }\end{array}$ & $\begin{array}{l}\text { Credits are not available in the mandatory } \\
\text { private scheme. However, in the public } \\
\text { earnings-related scheme, the annual } \\
\text { pension contribution is a fixed sum of } \\
\text { which two thirds is paid by the employer } \\
\text { and the remainder by the employee. } \\
\text { While out of the workforce and receiving } \\
\text { parental benefits, double the amount of } \\
\text { the annual contribution is credited to } \\
\text { their public pension account. The state } \\
\text { pays two thirds and the individual pays } \\
\text { the remainder. The 'double credit' is } \\
\text { designed to compensate for the loss of } \\
\text { savings in private occupational pensions } \\
\text { during periods outside of work spent } \\
\text { caring (Danish Government, 2005; } \\
\text { Frericks et al., 2006; OECD, 2015). }\end{array}$ \\
\hline Britain & $\begin{array}{l}\text { Quasi-mandatory } \\
\text { contributions } \\
\text { (auto-enrolment) into } \\
\text { privately-administered } \\
\text { occupational pension funds } \\
\text { for those fulfilling certain } \\
\text { conditions (i.e. aged over } \\
\text { twenty-two years and } \\
\text { earning above a lower } \\
\text { income limit) }\end{array}$ & $\begin{array}{l}\text { Employers who are contributing to an } \\
\text { occupational fund on behalf of their } \\
\text { employee must continue to pay pension } \\
\text { contributions on behalf of their employee } \\
\text { while their employee is on Ordinary } \\
\text { Maternity Leave (twenty-six weeks) or } \\
\text { receiving Statutory Maternity Pay (up to } \\
\text { thirty-nine weeks). The employer } \\
\text { contributions are based on the value of } \\
\text { the employee's salary before they went on } \\
\text { leave (nidirect website, The Pensions } \\
\text { Advisory Service website). }\end{array}$ \\
\hline Germany & $\begin{array}{l}\text { Individuals make voluntary } \\
\text { contributions to private } \\
\text { pension schemes called } \\
\text { Riester pensions. }\end{array}$ & $\begin{array}{l}\text { The state provides subsidies and tax } \\
\text { deductions to individuals who contribute } \\
\text { at least } 4 \text { per cent of their income to a } \\
\text { Riester account. Riester subsidies are flat } \\
\text { rate, regardless of earnings, claimed as a } \\
\text { tax reduction or a lump sum payment } \\
\text { once a year. Individuals are paid a higher } \\
\text { annual subsidy depending on the number } \\
\text { of children they have. The subsidy is only } \\
\text { paid to one parent (usually the mother) } \\
\text { (Frericks et al., 2008; Bucher-Koenen, } \\
\text { 2010; Leitner, 2011; OECD, 2015). }\end{array}$ \\
\hline
\end{tabular}

*The data presented in this table is partly drawn from data presented in the report emerging from the Australian Human Rights Commission study (AHRC, 2013b).

** These schemes no longer exist in the form presented in this table. 
country's parental leave scheme. Credits made from flat-rate parental leave schemes that are based on the minimum wage are likely to be very low. A generous, earnings-related parental leave scheme will allow for credits that are more adequate in value. A statefunded addition to the existing parental leave scheme for crediting private pensions is likely to be more effective than compelling individuals to make the credit from an already low payment (AHRC, 2013b). At the same time, a system of private pension credits must be accessible to informal carers, and to parents and carers with no or precarious attachment to paid work, and, therefore, accessible independently of the parental leave system. Delivering such credits through the tax system must be done with caution so that all parents and carers can benefit, not just those who draw an income or pay taxes (as in the German scheme). A state-funded credit delivered directly into a person's private pension account is likely to avoid many of these potential pitfalls.

We found only one country - Britain - with a system in which employers are compelled to contribute to private pensions during periods of care. The uncommon nature of this arrangement is perhaps not surprising. Currently, many second tier private pension schemes involve mandatory or quasi-mandatory employer contributions to individual pension accounts (OECD, 2013, 190) (some involve mandatory employer contributions, others combine employer and employee contributions and some only involve mandatory employee contributions). The rate of contribution is usually set at a proportion of income (OECD, 2015). The pension contribution is effectively a part of their salary. At the same time, in most countries, the state (rather than the employer) provides an income to individuals during extended periods of absence from work due to caring responsibilities. In most countries, for example, paid parental leave is funded by the state (AHRC, 2013b). As it is the state providing the income to individuals during periods of absence from work, we would argue that it is a natural extension of this principle that the state also assumes responsibility for the pension contribution (or carer credit).

One country, Britain, provides an exception. In Britain, employers contributing to an occupational pension on behalf of an employee must continue to make pension contributions on behalf of that employee while the employee is on statutory maternity leave, or pay, at the rate that they were contributing before the employee went on leave. ${ }^{6}$ In Britain's statutory maternity pay scheme, individuals can receive paid leave for up to thirtynine weeks. The first six weeks is at 90 per cent of the individual's earnings before they went on leave (or the prevailing flat rate, whichever is higher), and the remaining period is at the flat-rate (or 90 per cent of previous earnings, whichever is lower). Employers pay the statutory maternity pay to their employees and the government reimburses the employer for 92 per cent of that payment (or 104.5 per cent in the case of small businesses) (Forbes, 2009). In this sense, while parental leave pay is for the most part state-funded, the way in which the scheme is administered means that employers pay the maternity pay and the pension contribution, and are then reimbursed the maternity pay component.

There is scope in other countries for employers to make pension contributions on behalf of their employees while they are absent from work due to caring responsibilities. Many employers globally provide parental leave pay to their employees, and include in this workplace entitlement the pension contribution (AHRC, 2013b). In some states, governments encourage employers to do this. In Sweden, for example, employer contributions to private pensions during periods of care are encouraged, and most employers comply (OECD, 2011). However, employer-funded carer credits are by their nature confined to those temporarily taking leave from employment, whereas state-funded 
credits have the capacity to encompass those people, like many carers of a person with a disability, who do not have any attachment to work for extended periods.

Hence, a search for models of carer credits in private pensions found few. While some models are emerging, the schemes are in their early stages. They vary in their design features and are limited in value and coverage, and categorically exclude informal carers. In addition, there has been no comprehensive policy or scholarly debate about what this new policy approach means for retirement incomes systems around the world and the principles that underpin them, and how we might go about understanding, developing and evaluating pension credits in private pension schemes. As a result, now is the ideal time for deep consideration of the optimal design features of such credit schemes, and their underpinning principles. The next section provides this discussion. It offers the first conceptual analysis of carer credits in private pensions, examining where they fit into the principles that underpin contemporary public and private retirement incomes systems. Then drawing on what we have learnt from pension credits in second tier public schemes, it sets out some lessons for credits in second tier private schemes.

\section{Discussion: recognising care in changing pension systems}

Ostensibly, carer credits in private pension schemes do not accord neatly with the existing principles underpinning either public or private retirement income schemes. They are transactions that occur outside of the mechanisms and principles governing public pension schemes and appear inconsistent with the principles and objectives underpinning private pension schemes. However, we argue that carer credits in private pension schemes are indeed consistent with the principles underpinning both the public and private pension systems. They are consistent with the principles underpinning carer credits in public systems because, like public credits, they recognise the important contribution made by people providing care and attempt to ameliorate the impact of those caring responsibilities on an individual's retirement income. On the surface, publicly funded carer credits to private pensions appear antithetical to the purported principles and objectives underpinning private pensions. However, when examined more closely, we argue, carer credits are not only consistent with the principles underpinning private pension schemes but can, in fact, strengthen those principles.

The rationale ${ }^{7}$ offered by proponents of private pension provision is that mandating or incentivising private pensions will meet the following principles and objectives:

- increase individual reserves of, and reliance on, private savings;

- increase the adequacy of retirement incomes and therefore standards of living in older age;

- smooth income over the life-course; and

- encourage and subsidise private savings for old age throughout the life-course to reduce public transfers to public pensions.

Publicly funded carer credits in private pension schemes are wholly consistent with these principles: they support people with interrupted labour market histories due to caring responsibilities to improve their private savings, increasing the adequacy of their retirement incomes; they support the large proportion of the population who have interrupted workforce histories to smooth their incomes over periods in which their caring responsibilities are more or less intensive; and, like the taxation concessions that 
already exist for contributions to private pension schemes, carer credits are a method of encouraging and subsidising private savings for old age throughout the life-course to augment the private pension balances available to people in old age.

Nor will the provision of publicly funded credits to private pension schemes intrinsically undermine the objective of fiscal savings. Such a move could shift government expenditure from spending on public pensions at the end of a person (or carer's) life to spending on credits to private pensions during a person's life, credits that are made to a private account that accumulates interest over time. ${ }^{8}$ In addition, the shift towards private provision already generates high levels of tax expenditure on subsidies for private pensions (Hughes and Sinfield, 2004). Hence, in most countries the state already plays a strong role as 'facilitator', encouraging and subsidising private pensions at various stages of the life-course (Hamilton, 2012; Foster, 2014), and these credits are extending the subsidies enjoyed by high income earners to parents or carers. One method of reducing the overall cost to the state of expenditure on carer credits in private schemes would be to reduce the regressive nature of taxation concessions on private pension contributions. Finally, if the alternative is moving carers into the workforce to make their own contributions to private pensions, the cost to the state of replacing the care that they were providing is estimated to be extremely high (Buckner and Yeandle, 2011; Hoenig and Page, 2012; Deloitte Access Economics, 2015; Reinhard et al., 2015) - likely to be significantly higher than paying for carer credits.

Publicly funded carer credits to private pensions are not only consistent with the principles and objectives of private pensions, they also have the potential to strengthen them. Currently, the gender inequalities in access to private pensions undermine the private pension systems' own objectives as set out above. Among those with interrupted workforce histories and whose opportunities to contribute to private pensions are hampered, private systems can at best only partially meet the objectives of improving retirement income adequacy, smoothing income over the life-course, and encouraging or subsidising private saving. Hence, publicly funded carer credits to private pension schemes are not only a method of more equitably recognising the contribution of those providing care and ameliorating the consequent gap in retirement incomes, but they are also consistent with and have the potential to strengthen the principles and objectives underpinning private pension systems.

For governments recognising this and contemplating the introduction of carer credits of this kind, and given the absence of any existing 'exemplar' models of carer credits in private pension schemes, what might these credits look like? Based on the evidence presented above, they should be underpinned by the following principles:

- People who provide care make a large social and economic contribution and this contribution should be recognised in private as well as public pension systems.

- As a result, governments have a responsibility to minimise the 'retirement income penalty' in private pension systems created by care provision.

- 'Private' pensions are a form of state-subsidised saving to improve standards of living in retirement, and carers have a right to state-subsidised saving and improved standards of living in retirement.

Drawing on the characteristics that are most effective in public schemes, some lessons for the design of carer credits in private schemes are as follows: 
- Carer credits need to be provided for both parental care and informal care (i.e. care for people with disability, long-term illness or frailty due to old age).

- Carer credits need to be equally available to women and men.

- Carer credits need to explicitly target low-income earners: credits to a system of private pensions that are accessible only to a small wealthier proportion of the population, or those on paid leave, will not achieve their desired objectives. Those in precarious work and on low or no incomes must be able to access the private pension system if they are to benefit from credits to private pensions.

- Carer credits can be earnings-related or flat rate, but the base rate in either system must be adequate to have an impact on savings. Moreover, there should be an adequate minimum credit level to protect those with low or no income when they assume caring responsibilities.

- Carer credits need not be dependent on complete labour market withdrawal. Continuing to provide full, partial or top-up credits for a specified time period after an individual returns to part-time work can both reduce disincentives to return to work and ameliorate inequalities in retirement incomes created by part-time work (not just periods when people are completely withdrawn from the labour market) (AHRC, 2013a; 2013b).

\section{Conclusion}

Pensions linked to workforce participation or earnings throughout the life-course, in particular second tier public and private pension schemes, create unequal outcomes for people who provide care. As the ageing population creates greater demand for unpaid care, unequal and inadequate pensions are likely to become a more pressing problem for a growing proportion of the population. Carer credits in public pension schemes have emerged in recognition of the contribution carers make, and to compensate, at least to some extent, for the effects that caring responsibilities have on people's retirement incomes. However, improvements to public carer credits that aim to mitigate inequalities created by care provision have been undermined by the shift towards private provision, which has no mechanism for recognising care and widens inequalities in retirement incomes. Ideally, a generous public pension would create significantly more equitable outcomes. However, if private pensions are the route being taken by governments globally, we need to consider how we can work within private pension schemes to address inequalities experienced by people who provide care. Carer credits in second tier, mandatory private pension schemes are one possible measure for doing so, and they require investigation as an option.

Pension systems are complex and highly varied across countries (OECD, 2013) and the potential for carer credits to be incorporated into the different pension regimes and the way in which this can take place will differ considerably across countries. This article provided the first review of international activity in the field of carer credits in private pensions in the search of an 'exemplar' model. It revealed that in a small number of countries, carer credits are being incorporated into their private pension systems, but this is rare and the measures are limited in value and coverage and do little to mitigate the care penalty. In addition, these measures are being introduced in the absence of comprehensive reflection on what the principles and objectives underpinning them should be, and which design characteristics will enable them to operate effectively to meet these objectives in a way that is consistent with these principles. 
In order to fill this gap, this article aimed to provide a framework to understand, design and evaluate carer credits in private schemes. Drawing on an analysis of the details emerging from a review of carer credits in private schemes, and of several decades of lessons learnt regarding carer credits to public schemes, the desirable characteristics of carer credits in private schemes were described. In addition, the principles and objectives underpinning them were presented to guide policy and scholarly debate on this emerging but important policy subject.

\section{Acknowledgements}

The data presented in this article emerges from research undertaken for the Australian Human Rights Commission, 'Investing in care: Recognising and valuing those who care', by the authors as part of a research team. The authors of this article would like to acknowledge the other members of the research team, Professor Bettina Cass and Dr Trish Hill from UNSW, and Dimity Hodge, Alison Aggarwal and Pooja Chowdhary from the Australian Human Rights Commission. The authors would also like to thank Professor Jay Ginn for very insightful feedback on this article.

\section{Notes}

1 The OECD defines 'quasi-mandatory' as schemes that are not mandatory but which achieve close to universal coverage of employees through industrial relations agreements (OECD, 2013).

2 The OECD taxonomy differs from the commonly used three pillar taxonomy offered by the World Bank (1994). The World Bank stated that the objective of the first pillar was poverty alleviation and redistribution, and the second pillar was savings and income replacement, and placed all mandatory publicly managed schemes (social assistance and social insurance) in the first pillar, mandatory privately managed schemes in the second pillar and voluntary in the third. In response to the view that mandatory, publicly managed social insurance schemes are more akin to savings and income replacement (rather than poverty alleviation), the OECD's (2013) taxonomy includes only social assistance pensions in the first tier and both public and private mandatory contributory schemes in the second. For the OECD, the third tier includes voluntary savings schemes - individual or employer provided - including voluntary (defined benefit or defined contribution) occupational pension schemes.

3 In some countries, credits are provided in the form of 'points' rather than years. In Germany, for example, the calculation of pension entitlement is based on the number of pension 'points' an individual has, where one 'point' is based on a year's contribution at the rate of average earnings (OECD, 2015). In Germany and other countries with a 'points' system, credits are in the form of 'points' towards their pension balance.

4 In a few cases, credits are based on a proportion of the value of the social security payment that the individual receives while providing care (AHRC, 2013b).

5 From 2010, the number of qualifying years was reduced from forty-four for men and thirty-nine for women to thirty for both men and women. In 2016, the number of qualifying years was increased to thirty-five years for men and women (OECD, 2015).

6 This is for those employees in defined contribution schemes. For those in defined benefit schemes, the period of statutory maternity leave is treated as 'pensionable service', and while on leave the employee's pension benefit accrues at the level of earnings prior to the commencement of maternity leave (The Pensions Advisory Service website).

7 The rationale for the shift towards private pensions has been the source of much dispute. Critics argue that the 'unsustainability' rationale about public pensions emerged from 'unduly alarmist' predictions about the ageing population (Blackburn, 2002) and that private pensions, also affected by pressures associated with population ageing, are not necessarily more 'sustainable' (Davies et al., 2010). Others 
argue that it is difficult to maintain the view that private pensions reduce pressure on public budgets when such large public subsidies are made to support private saving (Hughes and Sinfield, 2004; Dennis and Richardson, 2012). Some contend that private pensions do not necessarily improve adequacy of retirement incomes as many are left with inadequate pensions in a private system, due both to the way global economic shocks or pension fund collapses grossly deplete savings reserves and the way they poorly service those with interrupted workforce histories (Davies et al., 2010). This has led scholars to suggest that the shift towards private responsibility for pension accumulation is motivated more by political ideology than policy imperative (Davies et al., 2010; Ellison, 2006; AHRC, 2013b).

8 More work needs to be done to calculate these precise figures.

\section{References}

Advisory Committee on Equal Opportunities for Women and Men (ACEOWM) (2013) Opinion on Reducing the Gender Gap in Pensions, Brussels: European Commission.

Australian Human Rights Commission (AHRC) (2013a) Investing in Care: Recognising and Valuing Those Who Care, Vol. 1, Sydney: AHRC.

Australian Human Rights Commission (AHRC) (2013b) Investing in Care: Recognising and Valuing Those Who Care, Vol. 2, Technical Papers, Sydney: AHRC.

Arza, C. (2012) Pension Reforms and Gender Equality in Latin America, Gender and Development Paper No. 15, Geneva: United Nations Research Institute for Social Development.

Behrendt, C. (2000) 'Private pensions - a viable alternative? Their distributive effects in a comparative perspective', International Social Security Review, 53, 33-26.

Bettio, F., Tinios, P. and Betti, G. (2013) The Gender Gap in Pensions in the EU, Luxembourg: European Union.

Blackburn, R. (2002) Banking on Death, or Investing in Life: The History and Future of Pensions, London: Verso.

Bucher-Koenen, T. (2010) Financial Literacy and Private Old Age Provision in Germany, Discussion Paper No. 104, Munich: Center for Doctoral Studies in Economics.

Buckner, L. and Yeandle, S. (2011) Valuing Carers 2011 - Calculating the Value of Carers'Support, London: Carers UK.

Colombo, F., Llena-Nozal, A., Mercier, J. and Tjadens, F. (2011) Help Wanted? Providing and Paying for Long-term Care, Paris: OECD.

Courtin, E., Jemiai, N. and Mossialos, E. (2014) 'Mapping support policies for informal carers across the European Union', Health Policy, 118, 1, 84-94.

Danish Government (2005) National Strategy Report on the Danish Pension System, ec.europa.eu/social/BlobServlet?docld=5449\&langld=en [accessed 04.11.2015].

Davidson, P. (2012) Building Super on a Fair Foundation: Reform of the Taxation of Superannuation Contributions, ACOSS Paper 185, Sydney: Australian Council of Social Services.

Davies, B., Ginn, J. and Minns, R. (2010) Funded Pensions: What are they for? An Enquiry into Their Lesser Known Functions, Paper produced for the Open University Innovation Knowledge and Development Centre Financial Institutions and Economic Security Conference, London, 21-22 May 2009, http://www.open.ac.uk/ikd/documents/policy-briefs/ikd-fies-policy-paper-richard-minns.pdf [accessed 04.11.2015].

Deloitte Access Economics (2015) The Economic Value of Informal Care in 2015, http://carersaustralia. com.au/storage/Economic-Value-Informal-Care-Oct-2010.pdf[accessed 30.09.2015].

Dennis, R. and Richardson, D. (2012) Can the Taxpayer Afford 'Self-funded Retirement?, The Australia Institute Policy Brief No. 42, Canberra: The Australia Institute.

Department for Work and Pensions (DWP) (2006) Security in Retirement: Towards a New Pensions System, London: DWP, https://www.gov.uk/government/uploads/system/uploads/attachment_data/ file/272299/6841.pdf [accessed 04.11.2015]. 
Ebbinghaus, B. (2015), 'The privatization and marketization of pensions in Europe: a double transformation facing the crisis', European Policy Studies, 1, 1, 56-73.

Ellison, N. (2006) The Transformation of Welfare States?, Milton Park: Routledge.

Evandrou, M. and Glaser, K. (2003) 'Combining work and family life: the pension penalty of caring', Ageing and Society, 23, 583-92.

Forbes, K. (2009) 'Paid parental leave under (New) Labour', Social Policy Journal of New Zealand, 34, $12-24$.

Foster, L. (2014) 'Women's pensions in the European Union and the current economic crisis', Policy and Politics, 42, 4, 565-80.

Frericks, P. Maier, R. and de Graaf, W. (2006) 'Shifting the pension mix: consequences for Dutch and Danish women', Social Policy and Administration, 40, 5, 475-92.

Frericks, P. Maier, R. and de Graaf, W. (2008) 'Male norms and female adjustments: the influence of care credits on gender pension gaps in France and Germany', European Societies, 10, 197-09.

Fultz, E. (2011) Pension Crediting for Caregivers: Policies in Finland, France, Germany, Sweden, the United Kingdom, Canada, and Japan, Washington, DC: Institute for Women's Policy Research.

Fultz, E. and Steinhilber, S. (2004) 'Social security reform and gender equality: recent experience in central Europe', International Labour Review, 143, 3, 249-67.

Geerts, J., Willeme, P. and Mot, E. (2012), Projections for Germany, The Netherlands, Spain and Poland, ANCIEN (Assessing Needs of Care in European Nations) EU.

Ginn, J. (2001) 'From security to risk: pension privatisation and gender inequality', Catalyst Working Paper, London: Catalyst.

Ginn, J. and Arber, S. (2000) 'Gender, the generational contract and pension privatisation', in S. Arber and C. Attias-Donfut (eds.), The Myth of Generational Conflict, London: Routledge, 133-53.

Ginn, J. and Macintyre, K. (2013) 'UK pension reforms: is gender still an issue?', Social Policy and Society, 12, 1, 91-103.

Hamilton, M. (2012) 'Just deserts? 'Privatisation' and the history of deservingness in Australia's retirement incomes system', Australian Journal of Social Issues, 47, 4, 457-77.

Hoenig, S. and Page, A.R.E. (2012) Counting on Care Work in Australia, Economic Security4Women, Australia: AECgroup Limited.

Holzmann, R. (2012) 'Global pension systems and their reform: worldwide drivers, trends and challenges', Social Protection and Labor Discussion Paper No. 1213, Washington, DC: The World Bank.

Hughes, G. and Sinfield, A. (2004) 'Financing pensions by stealth: the Anglo-American model and the cost and distribution of tax benefits for private pensions', in G. Hughes and J. Stewart (eds.), Reforming Pensions in Europe, Cheltenham: Edward Elgar, 163-192.

Jankowski, J. (2011) 'Caregiver credits in France, Germany and Sweden: lessons for the United States', Social Security Bulletin, 71, 461-71.

Leitner, S. (2011) 'Germany 2011: effects of life courses on women's pensions', Synthesis Report, Peer Review in Social Protection and Social Inclusion, European Commission Directorate General for Employment, Social Affairs and Inclusion, http://ec.europa.eu/social/BlobServlet?docld=8111\&langld=en [accessed 04.11.2015].

Mohring, K. (2014) 'Employment histories and pension incomes in Europe', European Societies, 17, 1, $3-26$.

nidirect website https://www.nidirect.gov.uk/articles/entitlements-during-statutory-maternity-leave [accessed 08.04.2016].

Organisation for Economic Cooperation and Development (OECD) (2011) Pensions at a Glance 2011: Retirement-income Systems in OECD and G20 Countries, Paris: OECD.

Organisation for Economic Cooperation and Development (OECD) (2013) Pensions at a Glance 2013. OECD and G20 Indicators, Paris: OECD.

Organisation for Economic Cooperation and Development (OECD) (2015) Pensions at a Glance 2015. OECD and G20 Indicators, Paris: OECD. 
Olsberg, D. (2004) 'Women and Superannuation: Still MS ... ing Out', Journal of Australian Political Economy, 53, 161-78.

Orenstein, M. (2008) Privatizing Pensions: The Transnational Campaign for Social Security Reform, Princeton, NJ: Princeton University Press.

Pickard, L., Wittenberg, R., Comas-Herrera, A., Davies, B. and Darton, R. (2000) 'Relying on informal care in the new century? Informal care for elderly people in England to 2031', Ageing and Society, 20, 6, 745-72.

Pickard, L. (2015) A growing care gap? The supply of unpaid care for older people by their adult children in England to 2023', Ageing and Society, 35, 96-123.

Price, D. (2007) 'Closing the gender gap in retirement income: what difference will recent UK reforms make?', Journal of Social Policy, 36, 4, 561-5.

Reinhard, S., Feinberg, L., Choula, R. and Houser, A. (2015) 'Valuing the invaluable: 2015 update', AARP Public Policy Institute, Washington DC.

Renga, S., Molnar-Hidassy, D. and Tisheva, G. (2010) Direct and Indirect Gender Discrimination in OldAge Pensions in 33 European Countries, Report Produced by the European Network of Legal Experts in the Field of Gender Equality, Brussels: European Commission.

Samek Lodovici, M., Crepaldi, C., Corsi, M. and Naaf, S. (2011) The Socio-Economic Impact of Pension Systems on the Respective Situations of Women and Men and the Effects of Recent Trends in Pension Reforms. Synthesis Report: Final version, prepared for the European Commission by the Expert Group on Gender Equality and Social Inclusion, Health and Long-Term Care Issues, Brussels: European Commission.

Steinhilber, S. (2003) 'The gender impact of pension reforms: case studies of the Czech Republic, Hungary and Poland, in OECD', Reforming Public Pensions: Sharing the Experiences of Transition and OECD Countries, Paris: OECD, 243-61.

The Pensions Advisory Service, http://www.pensionsadvisoryservice.org.uk/about-pensions/when-thingschange/parental-leave [accessed 04.05.2016].

Thomson, C., Hill, T., Griffiths, M. and Bittman, M. (2008) Negotiating Caring and Employment: Final Report for ARC Linkage Project, Social Policy Research Centre, Sydney: UNSW.

Vlachantoni, A. (2008) 'Care credits in European pension systems', Centre for Research on Ageing Discussion Paper 0801, Highfield, Southampton: University of Southampton.

Vlachantoni, A. (2012) 'Financial inequality and gender in older people', Maturitas, 72, 104-7.

World Bank (1994) Averting the Old Age Crisis: Policies to Protect the Old and Promote Growth, Oxford: University Press. 